\title{
Pengaruh Pemberian Fungi Mikoriza Arbuskula (FMA) dan PGPR terhadap Bintil Akar Tanaman Kedelai Hitam
}

\author{
Rama Adi Pratama, Kiki Zakiah \\ Fakultas Pertanian, Universitas Garut \\ E-mail : ramatarigan@uniga.ac.id
}

\begin{abstract}
ABSTRAK
Kedelai (Glycine $\max (\mathrm{L}$.$) Merril) merupakan tanaman pangan yang penting$ sebagai sumber protein nabati. Penelitian ini akan dilakukan di Kecamatan Tarogong Kaler Kabupaten Garut. Tujuan penelitian ini adalah untuk mengetahui pengaruh pemberian FMA dan PGPR terhadap jumlah bintil total dan persentase bintil efektif. Lokasi penelitian berada pada ketinggian tempat 650 meter. Rancangan pada penelitian ini menggunakan Rancangan Acak Kelompok (RAK) Faktorial yang terdiri dari 2 faktor yaitu empat taraf konsentrasi PGPR dan empat taraf inokulan FMA. Tiap perlakuan diulang sebanyak dua kali, maka jumlah keseluruhan : 4 × 4 × $2=32$. Hasil menunjukkan bahwa pengaruh pemberian FMA dan PGPR memberikan pengaruh yang nonsignifikan terhadap jumlah bintil total dan persentase bintil efektif.
\end{abstract}

\section{PENDAHULUAN}

Kedelai (Glycine $\max$ (L.) Merril) merupakan tanaman pangan yang penting sebagai sumber protein nabati. Kedelai juga merupakan komoditas yang telah dibudidayakan di Indonesia sebagai bahan baku industri pangan dan non pangan. Di Indonesia terdapat dua macam kedelai yang berkembang, yaitu kedelai kuning dan kedelai hitam. Kedelai kuning memiliki kandungan lemak lebih tinggi, sehingga sering digunakan sebagai bahan baku pembuatan minyak kedelai. Kedelai hitam memiliki kandugan lemak yang lebih rendah dan memiliki kandungan protein lebih tinggi. Kedelai hitam merupakan bahan baku utama dalam industri kecap.

Kedelai hitam mempunyai kandungan fenolik, tanin, antosianin dan isoflavon serta aktivitas antioksidan lebih tinggi dibanding kedelai kuning (Xu dan Chang, 2007). Menurut Xu dan Chang (2007) kedelai hitam kandungan flavonoidnya 6 kali lebih banyak dibanding kedelai kuning (kandungan total flavonoid kedelai kuning dan hitam berturut-turut 0,41 dan 2,57 mg ekuivalen dengan katekin per gram) dan aktivitas antioksidan 15 kali lebih tinggi (DPPH scavenging capacity kedelai kuning dan hitam berturut-turut 1,40 dan 17,58 $\mu \mathrm{mol}$ 
ekuivalen Trolox per gram) sedangkan menurut Astadi dkk, (2009) kulit kedelai hitam varietas Mallika memiliki kandungan antosianin 1,36 g/100 g dan senyawa fenolik 6,46 g/100 g.

Berkembangnya industri kecap di Indonesia secara langsung berpengaruh terhadap peningkatan kebutuhan akan kedelai hitam. Berdasarkan laporan Badan Pusat Statistik bahwa produksi kedelai pada tahun 2014 adalah 15,51 kuintal per hektar meningkat sebanyak 1,16\% menjadi 15,69 kuintal per hektar pada tahun 2015 (Badan Pusat Statistik, 2016). Walaupun terjadi peningkatan hal tersebut masih belum dapat mencukupi kebutuhan akan kedelai nasional. Rendahnya tingkat produktivitas ini menyebabkan tidak terpenuhinya kebutuhan kedelai dalam negeri dengan kondisi permintaan dan kebutuhan masyarakat dari tahun ke tahun yang terus meningkat seiring dengan bertambahnya jumlah penduduk. Oleh karena itu, perlu adanya peningkatan mutu benih untuk menghasilkan produktivitas yang tinggi dengan mutu benih yang tinggi pula, sehingga ketersediaan benih bermutu dapat terwujud dalam rangka mendukung swasembada kedelai.

Ketersediaan varietas benih kedelai hitam yang bermutu itu sendiri jumlahnya masih terbatas. Faktor pembatas produksi kedelai salah satunya adalah benih yang bermutu (Anggraeni dan Suwarno, 2013). Menurut Baihaki (2002) bahwa penggunaan benih kedelai yang bersertifikat oleh petani masih sangat rendah yaitu sekitar 5\%. Cara yang dapat dilakukan untuk mendapatkan varietas yang unggul yaitu melalui seleksi, introduksi dan persilangan. Adanya perbedaan respon genotipe terhadap lingkungan menyebabkan timbulnya perbedaan fenotipe pada setiap tanaman. Dari penampilan fenotipe tersebut suatu perbedaan sifat karakter dapat diketahui apakah di pengaruhi oleh genetik atau lingkungan sehingga dapat memudahkan pemulia untuk melakukan proses seleksi setiap genotipe untuk mengetahui genotipe yang lebih baik pada suatu daerah (Welsh, 2005).

Selain pemilihan benih yang bermutu, aspek budidaya dan kualitas tanah juga harus diperhatikan. Kedelai sebagai tanaman semusim menyerap N, P dan K dalam jumlah relatif besar. Untuk mendapatkan hasil kedelai yang tinggi diperlukan hara mineral dalam jumlah yang cukup dan seimbang. Namun demikian, pemberian pupuk anorganik secara intensif dan bahan lain yang kurang ramah terhadap tanah akan mengakibatkan kondisi tanah menurun dan tergolong lahan sakit. Oleh karena itu, pemberian pupuk anorganik harus diimbangi dengan pemberian pupuk organik dan pupuk hayati.

Pupuk organik berperan penting dalam meningkatkan serta mempertahankan kualitas tanah. Pupuk hayati juga membantu meningkatkan efisiensi serapan hara, memperbaiki pertumbuhan dan hasil tanaman, serta meningkatkan ketahanan hama dan penyakit. Kualitas tanah dan serapan yang baik akan menopang pertumbuhan dan produktivitas tanaman. Pupuk hayati mengandung mikroorganisme yang berguna bagi tanaman. 
PGPR (Plant Growth Promoting Rhizobacteria) adalah bakteri pengoloni akar yang memberikan efek menguntungkan terhadap pertumbuhan tanaman. Mekanisme PGPR dalam meningkatkan pertumbuhan tanaman adalah sebagai biostimulan yaitu mampu menghasilkan atau mengubah konsentrasi hormon tanaman seperti asam indolasetat, asam giberelat, sitokinin dan etilen atau prekusornya di dalam tanaman, tidak bersimbiotik dalam fiksasi N2, melarutkan fosfat mineral, memengaruhi pembintilan atau menguasai bintil akar; (2) bioprotectants, PGPR memberi efek antagonis terhadap patogen tanaman melalui beberapa cara yaitu produksi antibiotik, siderofore, enzim kitinase, B-1,3glucanase, sianida, parasitisme, kompetisi sumber nutrisi dan relung ekologi, menginduksi ketahanan tanaman secara sistemik (Fernando dkk,2005).

Salah satu pupuk hayati yang sesuai digunakan adalah Fungi Mikoriza Arbuskula (FMA). FMA merupakan asosiasi antara tumbuhan dan jamur yang hidup dalam tanah (Vierheilig et al., 2005). Sejalan dengan pendapat Barber, (1984) bahwa perakaran tanaman yang diinokulasikan FMA ternyata lebih efisien karena penyerapan air dan hara dibantu oleh jamur tersebut. Benang-benang hifa jamur memiliki akses dan jangkauan lebih luas dalam mengeksploitasi nutrisi pada suatu area tanah.

Peranan FMA di dalam tanah dapat ditingkatkan dengan penambahan pupuk hayati lain yaitu bakteri PGPR yang mampu bersinergi dengan FMA di dalam daerah perakaran. Toljander et.al. (2007) menyatakan terdapat kecenderungan pengaruh bakteri di dalam perakaran terhadap aktivitas pertumbuhan dan perkecambahan spora FMA. Interaksi antara bakteri yang tergolong dengan mikoriza dapat melalui beberapa tahap yang berbeda, yaitu (1) pada pertumbuhan jamur saprofit dalam tanah, (2) pada mekanisme interaksi antara jamur simbion dengan akar tanaman inang, (3) pada penerimaan tanaman inang terhadap adanya infeksi akar. Dalam hal ini, bakteri mampu membantu pertumbuhan jamur pada tahap pertumbuhan saprofitiknya baik dalam rizosfer maupun permukaan akar. Bakteri yang melekat pada hifa menunjukan hubungan yang erat di antara keduanya (Dupponois, 2006).

Dupponois and Garbaye (1990) menemukan bahwa dalam keadaan nutrisi yang terbatas, bakteri dapat bertindak paling tidak melalui dua mekanisme yaitu pengaruh langsung dan detoksikasi terhadap media yang diperkaya metabolit jamur tersebut. Bakteri mampu mengekresikan beberapa asam organik seperti asam sitrat dan asam malat yang dimetabolisme oleh isolat jamur, akan tetapi dia juga mampu melawan molekul-molekul toksik seperti polifenol yang dalam hal ini bersifat toksik bagi jamur mikoriza.

Penggunaan PGPR di Indonesia sebagai biostimulan dan bioprotectant yang dikombinasikan dengan FMA sampai saat ini masih belum banyak, padahal keduanya sebagai Berdasarkan potensi PGPR dan FMA serta manfaat dari kedelai hitam yang telah diuraikan, maka perlu dilakukan penelitian mengenai 
peningkatan pertumbuhan dan hasil tanaman kedelai hitam dengan menggunakan PGPR dan FMA.

\section{METODE PENELITIAN}

Penelitian ini akan dilakukan di Kecamatan Tarogong Kaler Kabupaten Garut. Lokasi penelitian berada pada ketinggian tempat 650 meter. Rancangan pada penelitian ini menggunakan Rancangan Acak Kelompok (RAK) Faktorial yang terdiri dari 2 faktor yaitu empat taraf konsentrasi PGPR dan empat taraf inokulan FMA. Tiap perlakuan diulang sebanyak dua kali, maka jumlah keseluruhan : 4 × 4 × $2=32$

\section{HASIL DAN PEMBAHASAN}

Berdasarkan hasil analisis menunjukkan bahwa pengaruh pemberian PGPR dan FMA terhadap jumlah bintil akar total tidak terjadi interaksi. Pengaruh mandiri masing-masing perlakuan pun memberikan hasil yang nonsignifikan. Hasil analisis tersebut dapat dapat dilihat pada tabel 1.

Tabel 1. Pengaruh mandiri PGPR dan FMA terhadap Jumlah Bintil Total

\begin{tabular}{lrr}
\hline Perlakuan & Rata-rata & Notasi \\
\hline PGPR (P) & & \\
p1 & 13.00 & $\mathrm{a}$ \\
p2 & 15.88 & $\mathrm{a}$ \\
p3 & 13.38 & $\mathrm{a}$ \\
p4 & 13.13 & $\mathrm{a}$ \\
\hline Inokulan FMA (G) & & \\
g1 & 12.50 & $\mathrm{a}$ \\
g2 & 16.75 & $\mathrm{a}$ \\
g3 & 12.63 & $\mathrm{a}$ \\
g4 & 13.50 & $\mathrm{a}$ \\
\hline Ke
\end{tabular}

Keterangan : huruf yang sama menunjukkan tidak berbeda nyata

Jumlah bintil total tidak memberikan pengaruh yang signifikan. Hal ini diduga bakteri dan fungi yang bekerja di dalam tanah masih belum mampu berasosiasi dengan bintil akar. Sehingga hasil dari pemberian perlakuan PGPR dan FMA memberikan hasil yang nonsignifikan pada tanaman kedelai hitam.

Pada pengamatan persentase bintil akar efektif hasil analisis menunjukkan bahwa tidak terjadi interaksi antara pemberian PGPR dan FMA. Selain itu 
memberikan hasil yang nonsignifikan terhadap masing-masing perlakuan. Hasil analisis tersajikan pada Tabel 2.

Tabel 2. Pengaruh mandiri PGPR dan FMA terhadap persentase Bintil Efektif (\%)

\begin{tabular}{lrr}
\hline Perlakuan & Rata-rata & Notasi \\
\hline PGPR (P) & & \\
p1 & 58.52 & $\mathrm{~A}$ \\
p2 & 56.99 & $\mathrm{~A}$ \\
p3 & 52.35 & $\mathrm{~A}$ \\
p4 & 53.58 & $\mathrm{~A}$ \\
\hline Inokulan FMA (G) & & \\
g1 & 53.62 & $\mathrm{~A}$ \\
g2 & 55.58 & $\mathrm{~A}$ \\
g3 & 53.31 & $\mathrm{~A}$ \\
g4 & 58.93 & $\mathrm{~A}$ \\
\hline
\end{tabular}

Hasil analisis menunjukkan bahwa persentase bintil akar efektif tidak memberikan pengaruh yang nyata. Pemberian PGPR dan FMA belum mampu meningkatkan persentase bintil akar efektif pada tanaman kedelai hitam. Hal ini diduga PGPR dan FMA di daerah rhizosfer belum mampu bekerjasama dengan baik juga terhadap mikroorganisme disekitar perakar.

\section{KESIMPULAN DAN SARAN}

Tidak terjadi interaksi antara pengaruh pemberian PGPR dan FMA terhadap jumlah bintil total dan persentase bintil efektif. Perlu dilakukan penelitian lebih lanjut mengenai perlakuan yang sama dengan penambahan dosis tertentu.

\section{UCAPAN TERIMA KASIH}

Direktorat Riset dan Pengabdian Masyarakat. Direktorat Jenderal Penguatan Riset dan Pengembangan Kementrian Riset, Teknologi, dan Pendidikan Tinggi yang telah membantu dalam memberikan dana pada pelaksanaan Penelitian Dosen Pemula (PDP) 


\section{DAFTAR PUSTAKA}

Adisarwanto, 2008. Budidaya Kedelai Tropika. Penebar Swadaya. Jakarta.

Astadi, I.R., M. Astuti, U. Santoso and P.S. Nugraheni. 2009. In vitro antioxidant activity of anthocyanins of black soybean seed coat in human low density lipoprotein (LDL). Food Chem., 122: 659-663.

Anggraeni, N. D dan Faiza C. Suwarno, 2013. Kemampuan Benih Kedelai (Glycine max L.) untuk Mempertahankan Viabilitasnya setelah Didera dengan Etanol. Agrohorti. 1(4):34-44.

Badan Pusat Statistik, 2016. Produksi Tanaman Kedelai Indonesia. http//www.bps.go.id/ (Diakses 23 Maret 2016).

Barber, Stanley A. 1984. Soil Nutrient Bioavailability. Wiley Interscience Publication. United States of America.

Baihaki, A. 2002. Review Pemuliaan Tanaman dalam Industri Perbenihan Indonesia. Di dalam: E. Murniati dkk, Editor. Industri Benih di Indonesia Aspek Penunjang Pengembangan. Bogor (ID): Institut Pertanian Bogor. Hlm 1-6.

Biswas JC, Ladha JK, Dazzo FB. 2000. Rhizobial inoculation improves nutrient uptake and growth of lowland rice. Soil Sci. Soc.Am. J. 64:1644-1650.

Dupponois, Robin. 2006. Mycorrhiza Helper Bacteria : Their Ecological Impact in Mycorrhizal Symbiosis. Handbook of Microbial Fertilizers. The Haworth Press, Inc. United States of America.

Dupponois, Robin and Garbaye. 1990. Some Mechanisms Involved in Growth Stimulation of Ectomycorrhizal Fungi by Bacteria. Canadian Journal of Botany 68: 2148 - 2152 .

Fernando D, Nakkeeran, Zhang Yilan. 2005. biosynthesis of antibiotics by PGPR and its relation in biocontrol of plant diseases.dalam: Z.A. Siddiqui (ed.), PGPR: Biocontrol and Biofertilization 67-109. Springer, Dordrecht, The Netherland 